\title{
In Vitro Growth and Rapid Multiplication of Lilium japonicum $\mathrm{T}_{\mathrm{HUNB}}$.
}

\author{
Hirokazu Fukui, Nobuo Adachi, Tetsuo Hara and Mitsuo Nakamura \\ Faculty of Agriculture, Gifu University, \\ Gifu, 501-11, Japan
}

(Received March 9, 1989)

(Accepted June 5, 1989)

\begin{abstract}
The seeds, embryos and shoot tips of Lilium japonicum Thunb. (which was collected in September) were used as explant sources for primary culture. Aseptic seedlings were not feasible because of low germination percentage. A sixty-one percent of embryos formed bulblets in the medium free from growth regulators. The enlargement of bulblets was closely related to the elongation of roots. Shoot tips enlarged and formed two or three bulblets on the medium containing NAA. The formation of bulblets was prevented by BAP. Shoot tips cultured in the medium with BAP formed watery calli, masses of shoot meristems (MSM) or protuberance tissues. The MSM was distinct from a callus because the former has the epidermis, outer layer and inner layer. The outer layer of MSM differentiated many shoot buds randomly. The volume of MSM increased gradually during its repetitive subculturing on the medium containing $10^{-5} \mathrm{M}$ of BAP. The protuberance tissue was a cormoid which was made of a enlarged base plate. Rapid multiplication was accomplished through the bulb scale culture under the conditions free from NAA and BAP and the bulblet regeneration from the MSM on the medium containing $10^{-6} \mathrm{M}$ of NAA.
\end{abstract}

The floweres of L. japonicum have a good figure, a beautiful pink color, and a sweet small. However, L. japonicum has a lower multiplication rate by scale propagation than the other Lilium. The commercial multiplication, therefore, has been made through seeding. As the seedling causes a variation of flower color (white to pink) and needs four years to bring about anthesis, in vitro rapid multiplication has been desired. This study was undertaken with intent of seeking an efficient way to multiply rapidly $L$. japonicum in vitro.

\section{Materials and Methods}

The material plants of L. japonicum Thunb. at the full-sized stage of green capsule were collected in September in Miyamacho of Gifu Prefecture. The seeds, embryos and shoot tips were used as explant sources for primary culture. The seeds were taken out of surface-sterilized capsules by soaking for $15 \mathrm{~min}$ in $1 \%$ sodium hypochlorite containing $0.05 \%$ Tween 20 , and the embryos were cut out from the seeds. Shoot tips $(0.5 \mathrm{~mm})$ were cut out aseptically from the surface-sterilized bulblets which were proliferated through scale propagation. These explants were placed on the medium which was consisted of a Murashige and Skoog's medium (MS) supplemented with $0.3 \%$ sucrose, $0.7 \%$ agar and various combinations of 6-benzylaminopurine (BAP) and naphthaleneacetic acid (NAA). The medium $\mathrm{pH}$ was adjusted to 5.7. Cultures were maintained at $20^{\circ} \mathrm{C}$ under 300 lux with a $16 \mathrm{hr}$ photoperiod.

Rapid multiplication was accomplished by the scale culture and the bulblet regeneration from mass of shoot meristems (MSM) formed through shoot tip culture.

Tissues for histological examination were fixed in FAA (formaldehyde-acetic acid-ethyl alcohol), 
dehydrated with the normal butyl alcohol series, and embedded in paraffin and sectioned with a rotary microtome at $20 \mu \mathrm{m}$. The sections were stained with Mayer's Haematoxilin.

\section{Results.}

Aseptic seedling were not feasible for the establishment of cultures, because of low germination percentage (below 20\%).

\section{Primary culture}

Shoot tips and embryos were cultured for the purpose of establishment of primary culture.

\section{(1) Embryo culture}

The base of embryo enlarged and a bulblet was formed after eight weeks of in vitro culture (Fig. 1). The formation of bulblet from the embryo was restrained by increasing BAP and NAA concentrations, especially $10^{-5} \mathrm{M}$ plot (Fig. 2). A sixty-one percentage of embryos formed bulblets under conditions free from NAA and BAP.

The percentage of root elongated embryos from the cultured embryos was highest at the conditions free from BAP and NAA and the number of rooted embryos decreased as the BAP and NAA concentrations in the medium increased (Fig. 3).

The enlargement of bulblet closely related to the elongation of root $(r=0.61$ : where " $r$ " represents correlation coefficient), and the root elongation accelerated the enlargement of the bulblets formed from embryos.

\section{(2) Shoot tip culture}

Shoot tips enlarged and formed two or three bulblets on the medium containing NAA after fifteen weeks of in vitro culture (Table 1 and Fig. 1). The formation of bulblets was prevented by BAP, and no bulblet had been formed at $10^{-6} \mathrm{M}$ and $10^{-5} \mathrm{M}$ BAP.
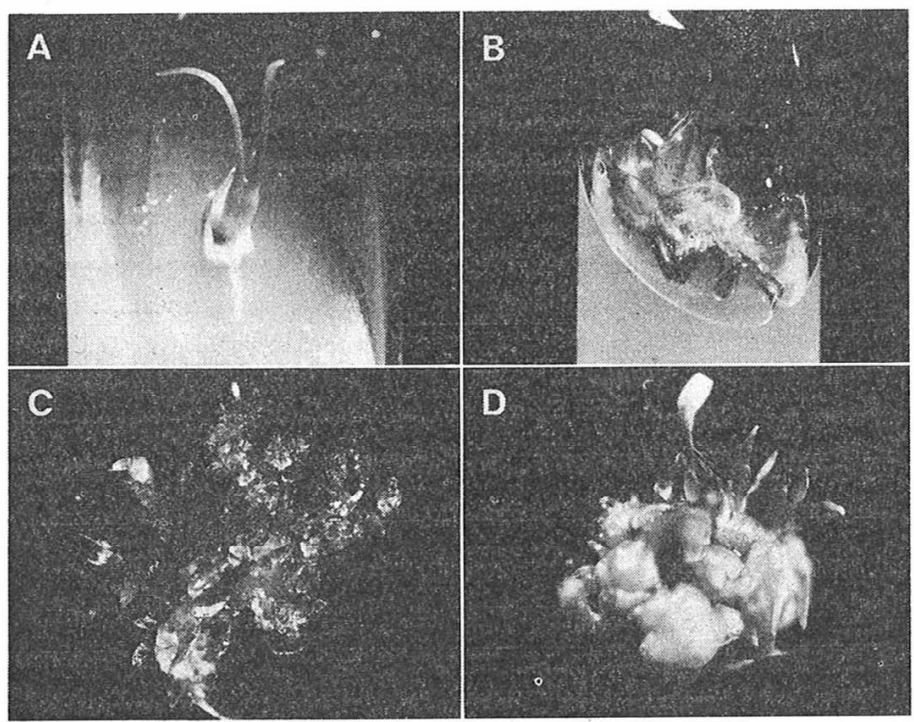

Fig. 1. Organogenesis of embryo or shoot tip of L. japonicum.

(A) Bulblet was formed from a embryo cultured on the medium without NAA and BAP. (B) Bulblets were formed from a shoot tip cultured on the medium containing $10^{-6} \mathrm{M}$ NAA. (C) Mass of shoot meristem (MSM) was formed from a shoot tip cultured on the medium containing $10^{-5} \mathrm{M}$ BAP. (D) Protuberance tissue was formed from a shoot tip cultured on the medium containing $10^{-6} \mathrm{M}$ BAP. 


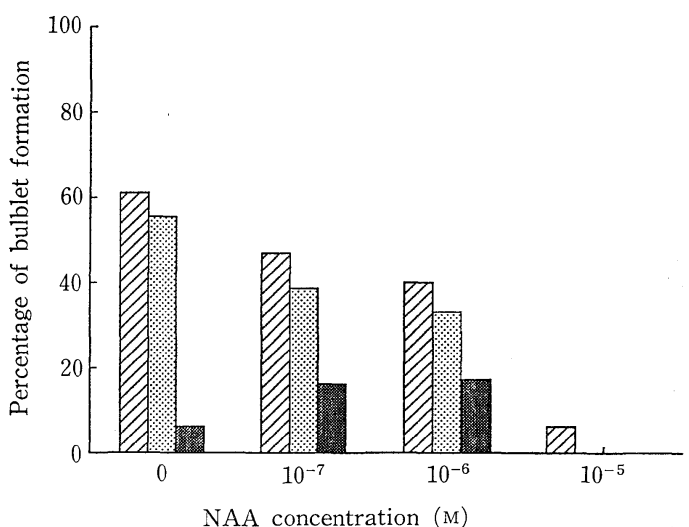

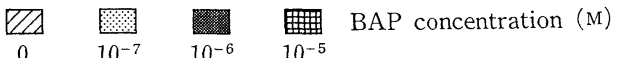

Fig. 2. Influence of NAA and BAP on bulblet formation of embryo.

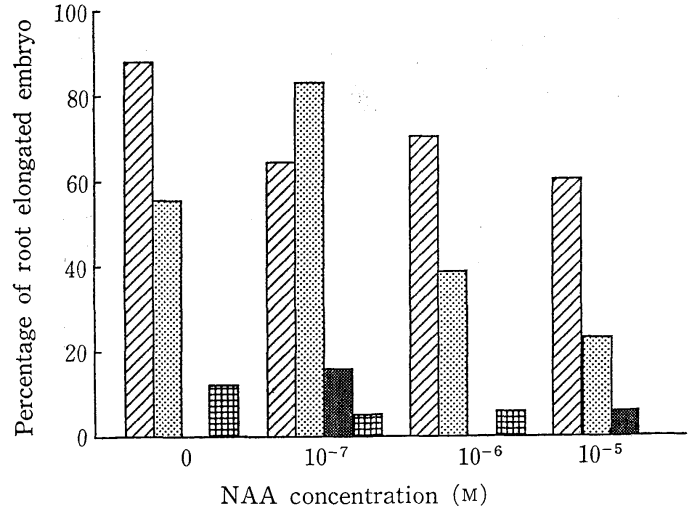

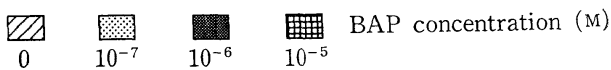

Fig. 3. Influence of NAA and BAP on percentage of root elongated embryos.

Table 1. Influence of NAA and BAP on organogenesis of shoot tip.

\begin{tabular}{lcccccccc}
\hline & & \multicolumn{3}{c}{ NAA (M) } & & \multicolumn{3}{c}{ BAP (M) } \\
\cline { 7 - 8 } & 0 & $10^{-7}$ & $10^{-6}$ & $10^{-5}$ & & $10^{-7}$ & $10^{-6}$ & $10^{-5}$ \\
\hline Bulblet formation (\%) & 100.0 & 66.7 & 87.5 & 62.5 & & 16.7 & 0 & 0 \\
Number or bulblet/shoot tip & 1.0 & 2.3 & 2.0 & 32 & & 1.0 & - & - \\
Diameter of bulblet (mm) & 1.9 & 4.9 & 4.6 & 3.8 & & 5.0 & - & - \\
Callusing (\%) & 12.5 & 16.7 & 0 & 0 & & 16.7 & 20.0 & 0 \\
Mass of shoot meristems (\%) & 0 & 0 & 0 & 0 & & 20.0 & 60.0 \\
Protuberance tissues (\%) & 0 & 0 & 0 & 0 & & & 60.0 & 40.0 \\
\hline
\end{tabular}

Shoot tips formed watery calli, masses of shoot meristems (MSM) or protuberance tissues, just as protocorm-like body, under conditions containing BAP (Table 1 and Fig. 1). The MSM had three morphological constitutions: (1) epidermis, which was not recognized sometimes, (2) outer layer with meristematic and much cytoplasmic cells, and (3) inner layer with large vacuolated cells (Fig. 4). The outer layer of MSM differentiated many shoot buds randomly (Fig. 4). The protuberance tissue was not a bulblet but a cormoid which was constructed from an enlarged base plate (Fig. 4).

\section{Rapid multiplication}

Rapid multiplication was accomplished through two attempts. One was a bulb scale culture and the other was bulblet regeneration from the MSM.

The explants for bulb scale culture were cut out from bulblets derived from shoot tips at $10^{-6} \mathrm{M}$ NAA. The bulblets regeneration from bulb scales was prevented in high concentrations of BAP, especially $10^{-5} \mathrm{M}$ (Fig. 5). The percentage of bulblet formation at $10^{-7} \mathrm{M}$ to $10^{-6} \mathrm{M}$ NAA was the same at the conditions free from NAA, and the addition of $10^{-7}$ and $10^{-6} \mathrm{M}$ NAA had no effect on increment of the bulblet regeneration percentage (Fig. 5 a), but the addition of NAA increased the number of bulblets from a single scale (Fig. $\mathbf{5}$ b). As four scales were cut out from the bulblet and each scale regenerated three bulblets on the average, one bulblet was multiplied twelve-fold after six weeks culture.

The MSM increased gradually by repetitive subculturing on a medium containing $10^{-5} \mathrm{M}$ BAP. The MSM was cut into pieces with various sizes, and then placed on a medium containing $10^{-6} \mathrm{M}$ NAA. All MSM pieces formed many bulblets regardless of its size. Figure 6 showed that therew as a linear 


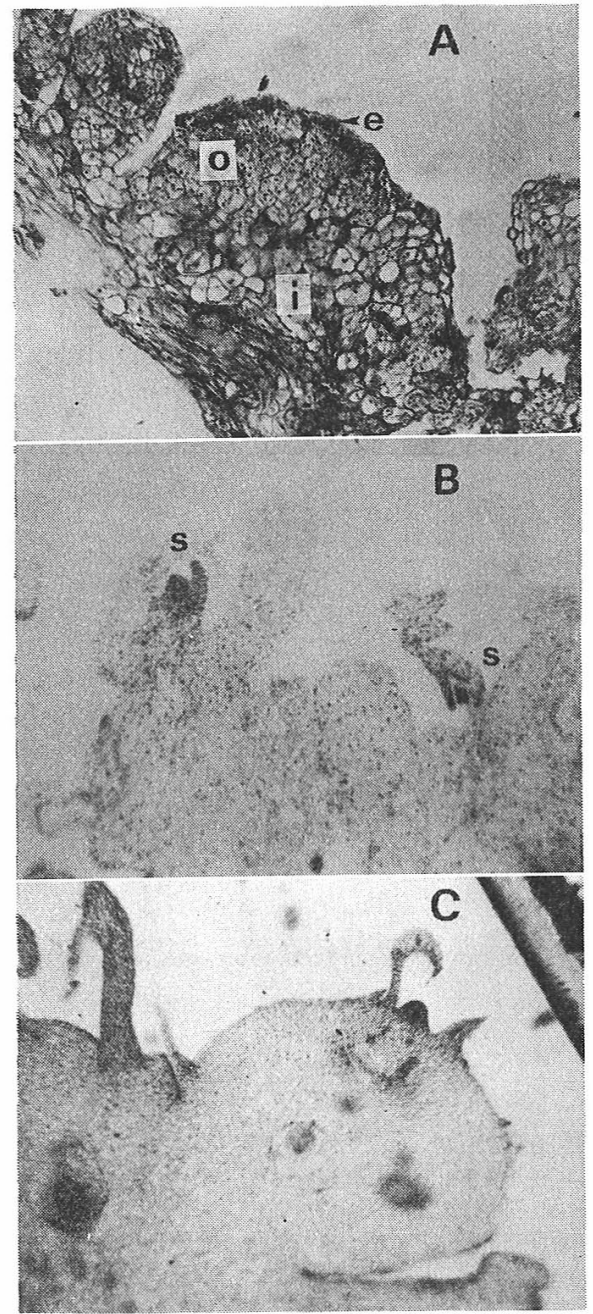

Fig. 4. Longitudinal section of mass of shoot meristem (MSM) and protuberance tissue. (A) Mass of shoot meristem (MSM) had epidermis (e), outer layer (o) and inner layer (i). (B) Outer layer of MSM differentiated many shoot buds (s). (C) Protuberance tissue was not scaly bulb.
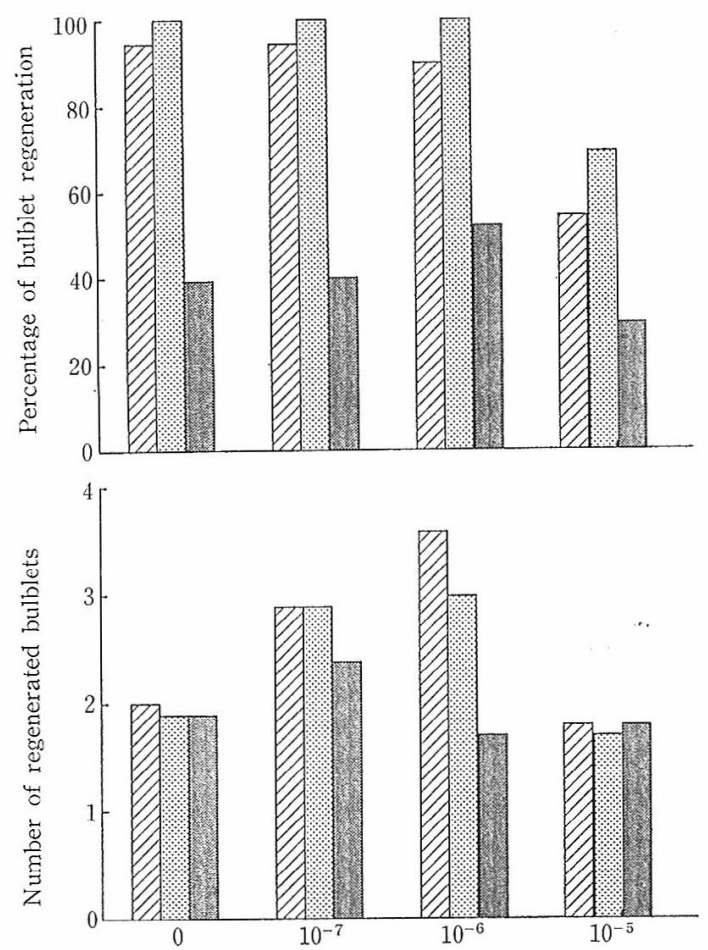

NAA concentration (M)

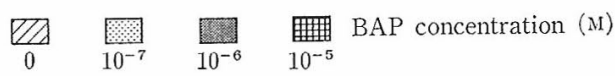

Fig. 5. Influence of NAA and BAP on bulblet regeneration from bulb scale in vitro.

relationship between the size of the MSM and the number of developed bulblets, and that the MSM at $5 \mathrm{~mm}$ in diameter developed about seven bulblets.

\section{Discussion}

Micropropagation through bulb scale culture achieved a good results in L. longiflorum, ${ }^{1}$ L. auratum $^{2)}$ and L. rebellum..$^{3)}$ The bulb scales were, however, barely suitable for explants in primary culture, because it had been difficult to disinfest the contamination by soil microorganisms ${ }^{4,5}$ in bulb scales. Furthermore, if mother plant contained viruses : lily symptomless virus (LSV), tulip breaking virus (TBV) or cucumber mosaic virus (CMV), the multiplied bulblets might be affected by these virus 


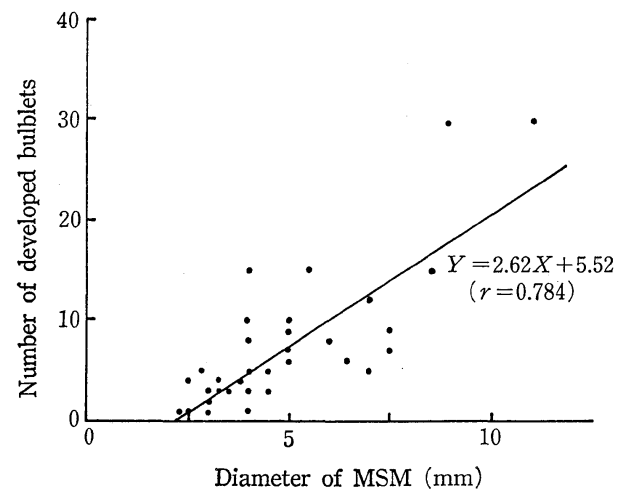

Fig. 6. Relationship in multiplication by mass of shoot meristem (MSM) between a size of the MSM and a number of developed bulblets on the medium containing $10^{-6} \mathrm{M}$ NAA.

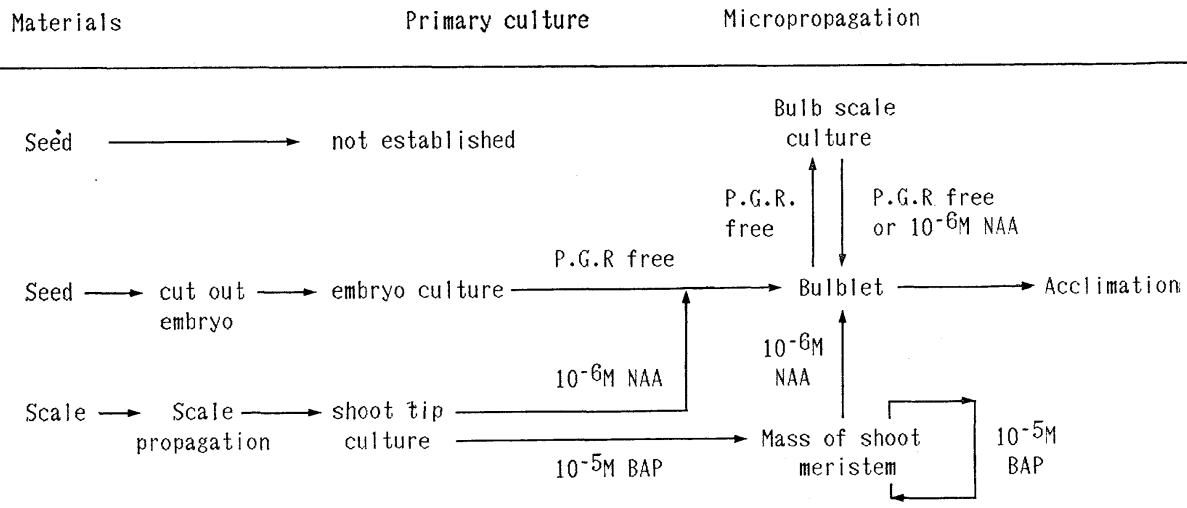

Fig. 7. The scheme for effective micropropagation in L. japonicum.

diseases. The micropropagation through bulblet formation from various tissues : leaf-, filament-, styleand stem-segment $t^{4,6)}$, had also the same defects in bulb scale culture. On the contrary, embryo or shoot tip is free from transmission of these viruses and these tissues have a high potential of plantlet regeneration, therefore the two tissues are considered to be suitable for explant in primary culture.

In this experiment, the cultured embryo formed a bulblet under conditions free from growth regulators, and the addition of NAA or BAP restrained bulblet formation. Asano et al. ${ }^{7}$, however, represented the result that the addition of NAA was effective for the direct germination of immature embryos $(0.4-0.8 \mathrm{~mm})$ in vitro. The difference of medium on bulb formation from embryo is attributable to the developmental stage of embryo; the bulb formation from mature embryo as in this experiment was germination and that from immature embryo as in Asano et al. 's result was organogenesis. from embryo tissue by NAA which also accelerated the bulblets formation in shoot tips.

Shoot tips formed mass of shoot meristems (MSM) under conditions containing $10^{-5} \mathrm{M}$ BAP. Banerjee et al. ${ }^{8)}$ observed the multiple bud formation from a single apex in $M u s a$, and a process of the formation was as follows: subsequently to expansion of the apical dome, ridges and lobes appeared in apical zone, and then formed new apices. Tanaka et al. ${ }^{9)}$ reported a continuous formation of shoot primordia (mass of shoot primordia) from shoot tip in a liquid culture. The mass of shoot meristems. (MSMs) had many meristematic cells with a potentiality of differentiating shoot buds, but had no apical zone and no primordia: The MSMs was therefore distinct from the multiple buds in Musa, the mass 
o shoot primordia, or a callus because MSMs were characterized by the three morphological constitutions; the epidermis, outer layer, inner layer.

The MSMs grew with repetitive subculturing on a medium containing $10^{-5} \mathrm{M} B A P$, and some part of the developed tissues transplanted to a medium containing $10^{-6} \mathrm{M}$ NAA induced bulblet formation.

From the above results, the scheme for effective micropropagation of $L$. japonicum is shown as in

Fig. 7. The bulblets established by embryo culture or shoot tip culture were micropropagated through bulb scale culture. Masses of shoot meristem formed from shoot tip with $10^{-5} \mathrm{M}$ BAP increased by repetitive subculturing on the same medium with $10^{-5} \mathrm{M}$ BAP, and the masses of shoot meristem regenerated the bulblets by transplanting the medium with $10^{-6} \mathrm{M}$ NAA. These bulblets were acclimated easely.

\title{
References
}

1) Stimart, D. P., P. D. Asher, 1978. J. Am. Soc. Hort. Sci., 103: 182-184.

2) Takayama, S., M. Misawa, 1980. Physiol. Plant., 48: 121-125.

3) Niimi, Y., 1985. J. Jpn. Soc. Hort. Sci., 54: 82-86.

4) Niimi, Y., H. Watanabe, 1982. J. Jpn. Soc. Hort. Sci., 51 : 344-349.

5) Liu, L., D. W. Burger, 1986. HortScience, $21: 1437-1438$.

6) Niimi, Y., T. Onozawa, 1979. Scientia Hortic., 11 : 379-389.

7) Asano, Y., H. Myoudo, 1977. J. Jpn. Soc. Hort. Sci., $46: 267-273$.

8) Banerjee, N., D. Vuylsteke, E. A.L. Delanghe, 1986. In "Plant Tissue Culture and Its Agricultural Applications" (ed. by Withers, L. A., P. G. Alderson), p. 139-147, Butterworths, London.

9) Tanaka, R., H. Ikeda, 1983. Jpn. J. Genet., 58:65-70.

\section{《和文要約》}

\author{
ササュリの in vitro での生長と大量増殖 \\ 福井博一, 安達延雄, 原 徹夫, 中村三夫 \\ 岐阜大学農学部
}

ササユリの大量増殖を目的とし, 無菌播種, 肧培養, 茎頂培養を行った. 無菌播種は発芽率が低く, 培養が確立しなかった。胚は生長調節物質無添加で子球を形成した. 茎頂組織は NAA $10^{-6} \mathrm{M}$ 添加培 地では子球を, BAP $10^{-5} \mathrm{M}$ 添加培地では生長点塊を形成した. 生長点塊は BAP $10^{-5} \mathrm{M}$ 添加培地で 継代培養すると増殖し, NAA $10^{-6} \mathrm{M}$ 添加培地に移植するてとにより多数の子球の形成が観察された. 肧, 茎頂組織㧍よび生長点塊から形成された子球のリン片を培養するととにより, リン片から新たな子 球の分化が認められた。したがって, ササユリの大量増殖法として, 生長点塊を増殖し, そこから子球 を形成させる方法と形成された子球のリン片培養を行う方法の 2 とおりが考えられる. 